\title{
Efficacy Study of Metho-Chelated Organic Minerals preparation Feeding on Milk Production and Fat Percentage in dairy cows
}

\author{
Somkuwar A.P. ${ }^{1}$, Kadam A.S ${ }^{2}$, Shiva Kumar $^{3} *$ and Radhakrishna P. M ${ }^{3}$ \\ 1 Department of Pharmacology \& Toxicology, 2 Department of Livestock Production and \\ Management, KNP College of Veterinary Science, Shirval, Maharashtra, India. \\ 3 Provimi India Innovation Centre, Provimi Animal Nutrition India Pvt. Ltd., IS-40, KHB \\ Industrial Area, Yelahanka New Town, Bangalore - 560 106, Karnataka \\ * Corresponding author
}

\begin{abstract}
The objective of the study was to compare the effect of feeding different mineral based formulation on dairy cow production performance, namely milk yield and fat percentage. The trial was conducted with dairy cows across various stages of lactation (Early, Mid and Late stage with 30 cows per stage). The experimental treatments included: Bestmin Gold (Metho-chelated organic minerals, given 30 gms per day), Inorganic mineral preparation (Inorg. Mineral, @ 50 $\mathrm{gms} / \mathrm{day} / \mathrm{cow}$ ) and control. The study lasted from 0 to 40 days. Milk yield and fat percentage of cows were measured individually on Days 0, 5, 10, 15, 20, 25, 30 and 40. The Bestmin Gold treated group (Metho-chelated organic minerals) improved the milk yield, net gain in milk and the milk fat percentage of animals across the various stages of lactation as compared to in control and inorganic mineral treated group of animals.
\end{abstract}

Keyw ords: Milk yield, Chelated, Mineral, Dairy cow, Milk Production, Dietary Supplementation.

\section{Introduction}

The benefits of supplementing organic trace minerals in dairy diets have been demonstrated in research and in the field. The traditional inorganic forms of trace minerals rapidly dissociate in the rumen and are free to interact with antagonists, resulting in the loss of the trace minerals prior to absorption by the animal (Henry et al., 1992; Ward et al.,1996). Chelated organic trace minerals are bound to organic ligands through coordinate covalent bonds. The bonds between the ligand and the mineral can prevent the mineral from interacting with antagonists and improve the bioavailability of the mineral (Ward et al., 1996; Bailey et al., 2001).

The basic reason for the use of organic forms of trace minerals is the reported increased bioavailability of organic vs. inorganic sources of the minerals. Although published reports have been quite variable when comparing organic and inorganic mineral availability, some evidence exists for advantages to supplementation with organic minerals. In general, it appears that organic trace minerals are useful and provide some advantage in situations involving antagonistic minerals, e.g. high levels of Mo, S, Fe, or $\mathrm{Zn}$ interfering with the availability of $\mathrm{Cu}$. Water quality must be considered when mineral antagonists are suspected. Organic minerals may be indicated in the following situations: 1) dry period of dairy cattle, 2) periparturient dairy cattle, 3 ) during stress (calving, transport, dramatic changes), and 4) in advance of breeding (30 to $60 \mathrm{~d}$ ) (Robert J.H., 2000).

The objective of the study was to determine the effects of supplementation of organic metho-chelated preparation, Bestmin Gold of Provimi Animal Nutrition India Private Limited, Bangalore, feeding on milk production, fat percentage and SNF percentage in dairy cows. Bestmin Gold is a formulation which contains metho-chelated minerals \& other trace minerals (Ca, P, Mg, Mn, Fe, I, Cu, Zn, Co, S, K, Na \& Se), stable vitamins (Vitamin A, D3, E \& B3) and bypass methionine complex which helps to overcome deficiency in ration and helps in increase of milk protein and fat percentage.

\section{Material and Methods}

The present study was carried out on some of the well-organized cattle farms in and around Phaltan town of Dist. Satara (Maharashtra) in collaboration with Dept. of Pharmacology and Toxicology, KNP College of Veterinary Science, Shirval Dist. Satara.

For this study 90 (Ninety) lactating cows were selected in such a way that 30 cow from each of the early, mid and late lactation stage. The selected cows from each of the lactation period were divided in such a way that each group consists of 10 cows.

Bestmin Gold was administered orally to the cows at the rate of $30 \mathrm{~g} /$ day/animal for 40 days. Inorganic mineral preparation (containing $\mathrm{Cu}, \mathrm{Co}$, 
Mg, Fe, Zn, I, Se, Mn, Ca, S, Na \& K) was administered to the cows at the rate of $50 \mathrm{~g} / \mathrm{cow} /$ day for forty days. The milk yield of individual cow was noted before the commencement of the treatment as well as on 5th, 10th, 15th, 20th, 25th, 30th, 35th and 40th day of the commencement of the treatment. On each of the milk-recording day the milk sample was subjected for the analysis of Fat $\%$ and SNF \% to find out the economic traits of the milk.

$\begin{array}{clc}\begin{array}{c}\text { Allocation of the Treatments: } \\ \text { Stage of } \\ \text { Lactation } \\ \text { Early }\end{array} & \begin{array}{l}\text { Treatment } \\ \text { Groups }\end{array} & \text { No. of Animal } \\ & \text { Bestmin Gold } & 10 \\ & \text { Inorganic mineral } & 10 \\ \text { Mid } & \text { Control } & 10 \\ & \text { Bestmin Gold } & 10 \\ & \text { Inorganic mineral } & 10 \\ \text { Late } & \text { Control } & 10 \\ & \text { Bestmin Gold } & 10 \\ & \text { Inorganic mineral } & 10 \\ & \text { Control } & 10\end{array}$

The comparison was carried out for milk yield, fat percentage in between different groups of the same lactation period as well as between the different groups of the different stages of lactations. The data were analyzed statistically and means were separated using Multiple Range Test (Snedecor and Cocharan, 1967).

\section{Results and Discussions}

The results of the various treatments on the milk yield in the different stages of lactation stages of cows are presented in Table 1. The control group of animals in early stage of lactation showed non significant increase in milk yield from $14.52 \pm 0.83$ liters to 14.78 \pm 0.79 liters after 40 days of observation period. The group of animals in early stage of lactation receiving treatment of organic minerals 'Methochelated Bestmin Gold' showed an increase of 0.880 liters, from its initial $13.61 \pm 1.18$ to $14.49 \pm 1.11$ liters at the end of treatment period. However this increase in the group of animals receiving inorganic minerals was found to be 0.5 liters from its initial $15.38 \pm 1.15$ to $15.88 \pm 1.12$ liters after completion of 40 days treatment period.
Percent wise it can be said that in the control group of animals the increase in milk yields was found to be $1.79 \%$ over an observation period of 40 days. This increase in the methochelated Bestmin Gold treated group of animals in early stage of lactation was found to be $6.47 \%$ similarly, this increase in inorganic mineral receiving group of animals was found to be $3.25 \%$ as compared to that of control group of animals. The percent increase in milk yield in Bestmin Gold treated group of animals was found to highly significant as compared to that of control and inorganic minerals treated group of animals.

Thirty cows in mid stage of lactation were equally divided in three groups. One group of cows was kept as control. The milk yield in this group was increased by 0.02 liters from its initial $12.41 \pm 0.36$ to $12.43 \pm 0.32$ liters after the observation period of forty days. This is a non-significant increase in milk yield. In second group of animals receiving methochelated Bestmin Gold (organic minerals) an increase in milk yield was found to be 0.63 liters from its initial $11.49 \pm$ 0.89 to $12.12 \pm 0.86$ liters after the treatment period of 40 days. Similarly, in the third group of animals receiving inorganic minerals an increase in milk yield was found to be 0.18 liters from its initial $12.14 \pm 0.40$ to $12.32 \pm 0.39$ liters after completion of 40 days observation period. In Bestmin gold treated animals increase in milk yield was found to be highly significant compared to that in inorganic minerals treated group and control group of animals.

In percentage, the control group of animals in mid lactation stage showed an increase in milk yield by $0.16 \%$ over an observation period of 40 days. In a group of animals receiving inorganic mineral supplement, increase in milk yield was found to be $1.48 \%$ after a treatment period of 40 days. Similarly, in a group of animals receiving organic methochelated Bestmin Gold increase in milk yield was found to be $5.49 \%$ after 40 days of treatment period. This increase in milk yield is highly significant compared to an increase in inorganic mineral treated and control group of animals.

Table-1: Average milk yield (in Ltrs.) in different lactation stages of cows receiving different treatments.

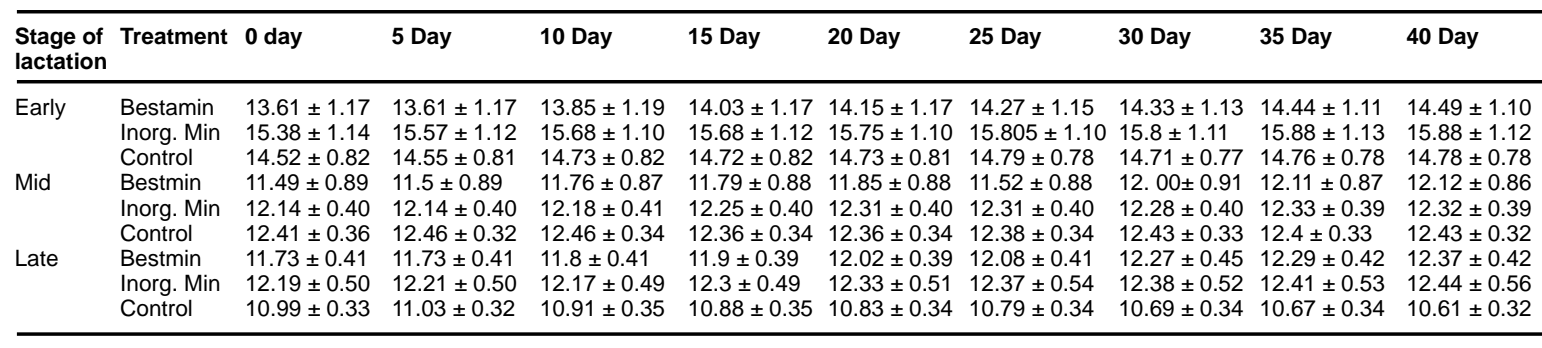


Efficacy Study of Metho-Chelated Organic Minerals preparation Feeding in dairy cows

Table-2: Average milk fat (in percentage) in different lactation stages of cows receiving different treatments.

\begin{tabular}{|c|c|c|c|c|c|c|c|c|c|c|}
\hline $\begin{array}{l}\text { Stage of } \\
\text { lactation }\end{array}$ & Treatment & 0 day & 5 Day & 10 Day & 15 Day & 20 Day & 25 Day & 30 Day & 35 Day & 40 Day \\
\hline Early & $\begin{array}{l}\text { Bestmin } \\
\text { Inorg. Min } \\
\text { Control }\end{array}$ & $\begin{array}{l}3.4 \pm 0.03 \\
3.73 \pm 0.14 \\
3.4 \pm 0.07\end{array}$ & $\begin{array}{l}3.4 \pm 0.03 \\
3.75 \pm 0.14 \\
3.4 \pm 0.07\end{array}$ & $\begin{array}{l}3.5 \pm 0.03 \\
3.78 \pm 0.12 \\
3.4 \pm 0.07\end{array}$ & $\begin{array}{l}3.5 \pm 0.02 \\
3.76 \pm 0.11 \\
3.4 \pm 0.07\end{array}$ & & $\begin{array}{l}3.6 \pm 0.03 \\
3.81 \pm 0.10 \\
3.4 \pm 0.06\end{array}$ & $\begin{array}{l}3.6 \pm 0.03 \\
3.83 \pm 0.11 \\
3.4 \pm 0.07\end{array}$ & $\begin{array}{l}3.6 \pm 0.03 \\
3.81 \pm 0.11 \\
3.4 \pm 0.07\end{array}$ & $\begin{array}{l}3.6 \pm 0.03 \\
3.82 \pm 0.11 \\
3.4 \pm 0.07\end{array}$ \\
\hline Mid & $\begin{array}{l}\text { Bestmin } \\
\text { Inorg. Min } \\
\text { Control }\end{array}$ & $\begin{array}{l}3.5 \pm 0.17 \\
3.39 \pm 0.11 \\
3.5 \pm 0.09\end{array}$ & $\begin{array}{l}3.5 \pm 0.17 \\
3.41 \pm 0.11 \\
3.5 \pm 0.08\end{array}$ & $\begin{array}{l}3.6 \pm 0.13 \\
3.44 \pm 0.11 \\
3.5 \pm 0.09\end{array}$ & $\begin{array}{l}3.6 \pm 0.11 \\
3.46 \pm 0.11 \\
3.5 \pm 0.08\end{array}$ & $\begin{array}{l}3.6 \pm 0.11 \\
3.5 \pm 0.11 \\
3.5 \pm 0.07\end{array}$ & $\begin{array}{l}3.6 \pm 0.11 \\
3.5 \pm 0.12 \\
3.5 \pm 0.07\end{array}$ & $\begin{array}{l}3.6 \pm 0.11 \\
3.48 \pm 0.10 \\
3.5 \pm 0.07\end{array}$ & $\begin{array}{l}3.6 \pm 0.09 \\
3.49 \pm 0.10 \\
3.5 \pm 0.07\end{array}$ & $\begin{array}{l}3.7 \pm 0.09 \\
3.47 \pm 0.10 \\
3.5 \pm 0.08\end{array}$ \\
\hline Late & $\begin{array}{l}\text { Bestmin } \\
\text { Inorg. Min } \\
\text { Control }\end{array}$ & $\begin{array}{l}3.5 \pm 0.11 \\
3.83 \pm 0.09 \\
3.5 \pm 0.09\end{array}$ & $\begin{array}{l}3.5 \pm 0.11 \\
4.11 \pm 0.27 \\
3.5 \pm 0.09\end{array}$ & $\begin{array}{l}3.5 \pm 0.10 \\
3.86 \pm 0.08 \\
3.5 \pm 0.08\end{array}$ & $\begin{array}{l}3.6 \pm 0.10 \\
3.87 \pm 0.06 \\
3.5 \pm 0.08\end{array}$ & $\begin{array}{l}3.6 \pm 0.10 \\
3.89 \pm 0.06 \\
3.5 \pm 0.08\end{array}$ & $\begin{array}{l}3.6 \pm 0.11 \\
3.9 \pm 0.07 \\
3.5 \pm 0.07\end{array}$ & $\begin{array}{l}3.7 \pm 0.10 \\
3.92 \pm 0.08 \\
3.5 \pm 0.07\end{array}$ & $\begin{array}{l}3.7 \pm .09 \\
3.9 \pm 0.06 \\
3.5 \pm 0.08\end{array}$ & $\begin{array}{l}3.7 \pm 0.09 \\
3.91 \pm 0.06 \\
3.5 \pm 0.08\end{array}$ \\
\hline
\end{tabular}

Thirty cows in late stage of lactation were also divided equally in three groups of animals. One of the groups kept as control and did not receive any treatment. In this group of animals the milk yield was decreased by 0.38 liters from its initial $10.99 \pm 0.33$ liters to $10.61 \pm 0.32$ liters after an observation period of 40 days. Where as in case of the animals receiving inorganic mineral supplement this increase in milk was observed to be 0.22 liters from its initial $12.19 \pm$ 0.50 to $12.41 \pm 0.58$ liters, after completion of 40 days treatment period. Similarly, in the groups of animals receiving organic minerals methochelated Bestmin Gold treatment the increase in milk yield was 0.64 liters after 40 days treatment period. Increase in milk yield in Bestmin Gold treated groups of animals is highly significant as compared to milk yield in control and inorganic mineral treated group of animals.

Percentage wise, the milk yield in control group of animals was decreased by $2.91 \%$ in the late lactation stage. Whereas in Bestmin Gold treated group of animals the milk yield was increased by 5.46 $\%$ instead by decrease as in case of control group of animals. This indicates net gain by $8.37 \%$ as compared to that in control group of animals. In case of inorganic minerals treated group of animals increase in milk yield was found to be $1.80 \%$ over the period of 40 days of treatment. In this group also the net gain in milk yield was found to be $4.71 \%$ as compared to milk yield in control group of animals.

The results of the various treatments on the fat percentage in the milk in the different stages of lactation stages of cows are presented in Table 2.The group of animals in early stage of lactation receiving methochelated Bestmin Gold organic mineral supplement showed an increase in milk fat percentage by $0.2 \%$ over a treatment period of 40 days. Whereas, this increase in inorganic mineral treated group of animals was found to be $0.09 \%$. An increase in milk fat percentage in Bestmin gold treated group of animals is highly significant as compared to that group receiving inorganic mineral treatment.

Similarly, in the group of animals receiving Methochelated Bestmin gold in mid and late stage of lactations also showed an increase in milk fat percentage by $0.2 \%$ which is highly significant compared to that in inorganic mineral treated group of animals $(0.08 \%)$.

It has been suggested that organic minerals have an increased bioavailability, resulting in an increased absorption in the gastrointestinal tract (Spears, 1996). This may lead to an improvement in performance or health or may reduce the level of mineral supplementation required in the diet. Nocek et al. (2006) who reported an increased milk production in animals receiving diets containing organically complexed minerals and a mixture of inorganic and organically complexed minerals. The above results are thus in agreement to the researchers that feeding of organic minerals improves milk yield and performance of the dairy cows.

\section{References}

1. Bailey, J. D., R. P. Ansotegui, J. A. Paterson, C. K. Swenson, and A. B. Johnson. (2001). Effects of supplementing combinations of inorganic and complexed copper on performance and liver mineral status of beef heifers consuming antagonists. J. Anim. Sci. 79:2926

2. Henry, P. R., C. B. Ammerman and R. C. Littell. (1992) Relative bioavailability of manganese from a manganesemethionine complex and inorganic sources for ruminants. $J$. Dairy Sci. 75: 3473-3478.

3. Nocek, J. E., M. T. Socha, and D. J. Tomlinson. (2006). The effect of trace mineral fortification level and source on performance of dairy cattle. J. Dairy Sci. 89:2679-2693.

4. Robert J. Harmon.(2000). When are Chelated Minerals Justified. Kentucky Ruminant Nutrition. pp. 47-54.

5. Snedecor, G.W. and W.G. Cocharan. (1967). Statistical methods, 6th Edn. The Iowa State Univ. Press, Ames, Iowa, USA.

6. Spears, J. W. (1996). Organic trace minerals in ruminant nutrition. Anim. Feed Sci. Technol. 58:151-163.

7. Ward, J. D., J. W. Spears and E. B. Kegley. (1996). Bioavailability of copper proteinate and copper carbonate relative to copper sulfate in cattle. J. Dairy Sci. 79: 127-132.

$* * * * * * * *$ 